\title{
Use of Organic Materials to Maintain Soil Quality by Thai-Lao Rice Farmers in Northeast Thailand
}

\author{
Sujitra Yodda ${ }^{1,2}$, Suwit Laohasiriwong ${ }^{1}$, and A. Terry Rambo ${ }^{1,2, *}$ \\ ${ }^{1}$ Program on System Approaches in Agriculture for Sustainable Development, Department of Agricultural \\ Extension and Agricultural Systems, Faculty of Agriculture, Khon Kaen University, Khon Kaen, Thailand. \\ 2 Soil Organic Matter Management Research Group of Khon Kaen University, Khon Kaen, Thailand. \\ * Correspondence author: trryrambo@yahoo.com; Tel.: +66-99-092-0219
}

\begin{abstract}
Maintaining soil quality is a major problem for traditional farmers in the tropics. Many rely on organic amendments to enhance the productivity of their fields. However, indigenous knowledge about soil organic matter (SOM) and its management has received relatively little attention from researchers. This paper describes the use of organic materials to maintain soil quality by Thai-Lao farmers in a rice-growing village in Northeast Thailand. In-depth semi-structured interviews were conducted with twelve farmers to: 1) identify the indicators of soil fertility they employed; 2) inventory the organic materials they used; 3 ) determine changes in the use of amendments over time; and 4) understand their concept of SOM. They used many physical and biological indicators of soil quality. They used nine different organic materials: rice straw and stubble, cattle, buffalo and pig manure, rice husks, sunn hemp plants as green manure, charcoal, commercial compost, homemade compost, and tree leaf litter. Recently, use of livestock manure, rice husks, charcoal, and leaf litter has declined because of supply shortages. They do not appear to have a general concept of organic matter nor is there a commonly used word for "organic" in their language. Most of the farmers would use larger quantities of organic amendments but are constrained by their scarcity and high cost. Ways to increase local supplies of organic materials must be found if the government's efforts to encourage the adoption of organic agriculture are to be successful.
\end{abstract}

Keywords: Ethnopedology; Agricultural sustainability; Farmer soil management; Manure; Green manure; Organic soil amendments; Soil quality indicators

\section{Introduction}

The land degradation that is an almost inevitable consequence of agriculture has presented a serious problem to farmers since they first began cultivating the soil many thousands of years ago. Loss of soil organic matter (SOM) resulting from soil disturbance caused by cultivation lowers soil quality and fertility with consequent reduction of crop yields. Traditional subsistence farmers in many parts of the world have attempted to maintain soil quality by adding organic amendments to their fields (Hossain, 2001; Grossman, 2003). This practice is also widespread among modern commercial farmers (Hijbeek et al., 2018). Use of organic amendments dates back thousands of years (McNeill \& Winiwarter, 2004). Analysis of $\mathrm{N}-15$ isotope concentrations in grain seeds recovered from a Neolithic era archeological site in Greece by Vaiglova et al., (2014) has shown that farmers were manuring their fields some 8,000 years ago. Farmers in China were adding organic amendments to their intensively cultivated paddy fields since as early as the third century BCE (Before Common Era) (McNeill \& Winiwarter, 2004). In East Asia, where animal manure was scarce, farmers used many other types of organic residues. In addition to pig and buffalo manure, Chinese rice farmers in the Tai Lake region have added human night soil, green manure, silkworm wastes, and oil cakes to their paddy fields since at least 1000 CE [common era] (Ellis \& Wang, 1997). Human night soil was widely used throughout the ancient world and continued in widespread use in China, Japan, and Korea until recent years (Kawa et al., 2019) but has rarely been employed by Southeast Asian farmers who rely on livestock manure, green manures, tree leaves, rice husks and other organic residues to maintain soil quality in their fields. For example, farmers in Northeast Thailand collect black organic soils from termite mounds and areas under the canopies of trees to incorporate in their commercial vegetable plots (Marten \& Vityakon,1986), while farmers in the central plain of Laos spread termite mound soil on their paddy fields to fertilize their rice crops (Miyagawa et al., 2011). 
Although it is well known that many traditional farmers apply organic residues to their fields, little is known about the indigenous concepts that guide their use of these materials. Do they, for example, have a clear concept of soil organic matter and understand how it affects soil quality? It has often been stated that the organic matter content of soil is used as an indicator of soil fertility by traditional farmers in many parts of the world (Barrera-Bassols and Zink, 2003), but there is scant empirical support for this view. Based on our own reading of a substantial number of studies of indigenous soil classification, we suspect that researchers have inferred that organic matter is the classificatory criterion when the native name does not actually include this term. Instead it refers to an associated characteristic of SOM. Having a black or dark brown color is perhaps the most commonly cited attribute (Hossain, 2001; Quansah et al., 2001). Being "fatty" and having the odor of fresh organic matter are also sometimes mentioned by farmers (Quansah et al., 2001). We have not encountered any convincing evidence that traditional farmers had a clearly defined concept of soil organic matter as a general category or recognized the role that it plays in maintaining overall soil quality.

Despite the important role that application of organic residues plays in maintaining soil quality in traditional agricultural systems, ethnopedological researchers have paid little attention to this key aspect of indigenous soil knowledge. Instead, their focus has been on documenting the soil classification systems of different ethnic groups while other aspects of indigenous soil knowledge have been largely ignored (Grossman, 2003). The paper by Pilbeam et al., (2005) on farmer practices and perceptions regarding the use of different amendments to manage soil fertility in the mid-hills of Nepal stands out as a rare exception. In order to help fill this knowledge gap we carried out an investigation of indigenous knowledge about soil organic matter and its management of farmers belonging to the Thai-Lao ethnic group in Northeast Thailand. In this research, we sought to go beyond documenting their soil taxonomies (Yodda \& Rambo, 2018; Yodda, 2019; Yodda et al., 2020) to document their use of organic materials to maintain soil quality and explore the concepts that guide their practices of soil management. In this paper we will 1) describe the indicators these farmers employ to assess soil quality, 2) inventory the different organic residues they employ to enhance soil quality in their paddy fields, 3) examine how use of these residues has changed over the past decade, and 4) discuss whether these farmers have a general concept of soil organic matter.

\section{Materials and Methods}

\subsection{Selection of the study site}

This study was conducted in Non Ku village (latitude $16^{\circ} 30^{\prime} 37^{\prime \prime} \mathrm{N}$ and longitude $102^{\circ} 39^{\prime} 56^{\prime \prime} \mathrm{E}$,) Sawathee sub-district, Mueang district, Khon Kaen province (Figure 1).This village was selected because it shared several important characteristics with the majority of villages in Northeastern Thailand: 1) Almost all of its residents were members of the Thai-Lao ethnic group, which constitutes the majority of the region's population; 2 ) the village was located on undulating terrain, which is the predominant land form in the region; 3 ) the village was located on land classified as belonging to the Roi-Et soil series, which is one of the most widespread soil series in the region; and 4) All of the paddy fields in the village were used to grow rainfed wet rice, which is the dominant cropping system in the Northeast. In addition, it had been the site of an earlier study (Yodda \& Rambo 2018) on the naming and classification of paddy soils by farmers belonging to the Thai-Lao ethnic group and thus we already had a good understanding of local soil knowledge.

According to village records in 2017 Non Ku had 290 households and a total population of 1,059 people, of which 531 were male and 528 female. One-third of the villagers were 51 years old and over. Most of the villagers belonged to the Thai-Lao ethnic group. Most households are engaged in agriculture with rain-fed wet rice as their main crop. A more detailed description of the village was presented in Yodda \& Rambo (2018).

\subsection{Selection of sample farmers}

A purposive sample of 12 farmers ( 8 men and 4 women) was selected based on their use of different types of organic materials to improve soil quality and increase the yield of rice. Their fields were located in different parts of the village and had different types of soil. Their landholdings 
ranged from 0.8 to 4.8 hectares, with an average holding of 1.9 ha. All of the informants were 60 years of age or older and were actively engaged in farming and had extended experience in soil management. All gave their informed consent to participate in this study after being assured that their anonymity would be protected by the researchers

The sample was not intended to be representative of the village population as a whole. Instead, it was deliberately limited to older farmers of at least 60 years of age. This was because we believed that older farmers, who had received much less formal education than younger ones, were more likely to retain indigenous knowledge about soil. The sample farmers ranged in age from 60 to 84 years with a mean age of 71.3 years. All had only completed primary school.

\subsection{Data collection}

During the period from September 2019 to January 2020, data were collected in a multi-step process which included the following steps.

\subsubsection{Eliciting indicators of soil quality used by farmers}

Each of the farmers was individually shown two soil samples including black-colored sandy soil (called din dam [black soil] in the Lao language) and light-colored sandy soil (called din sai [sandy soil] in Lao). The farmers were asked to indicate which soil they thought was more fertile and explain why they thought that. They were also asked if they used any other indicators of soil quality and fertility.

\subsubsection{Description of organic amendments used by the farmers in their paddy fields}

Each farmer was individually interviewed in his or her field about the organic materials they applied there. They were also questioned about the characteristics of each soil amendment they used, the quantities they applied, the sources from which they obtained these amendments, the benefits their use provided, and the constraints they encountered in using these amendments.

\subsubsection{Identifying changes over time in farmer use of organic amendments}

After a complete list of all the different types of organic amendments used in the village was compiled, the sample farmers were again individually interviewed about how their use of these residues had changed over time. They were asked which of these amendments they currently used, which ones they had used in the past but no longer used, and which ones they had never used. They were also asked about their reasons for using or not using each of the residues.

\subsubsection{Grouping of soil amendments into similar types by the farmers}

Each informant was shown eight plastic bags containing samples of commonly used soil amendments (chemical fertilizer, lime, sunn hemp plants, cow manure, pig manure, rice husks, rice straw, and tree leaves). They were requested to sort the samples into groups that they considered to be similar and to describe the reasons why they grouped certain samples together.

\section{Results}

\subsection{Indicators of soil fertility and quality employed by the farmers}

The farmers in Non Ku village used soil physical properties, the presence of certain animal and plant species, and the color and vigor of growth of their rice plants as indicators of soil fertility. Color and texture were the main physical properties used to assess soil quality. All of the farmers said that dark color was an indicator of high soil fertility. Coarse textured soil (which usually also has low SOM content) was considered to be low quality because it hardened quickly after harrowing, making it difficult to insert seedlings during transplanting, retained water poorly, and the rice plants grew poorly in it. However, if coarse textured soil was black colored it was considered to be good soil for growing rice. The farmers also employed several biological indicators of soil quality. Five farmers considered the presence of large numbers of earthworms to be an indicator of high soil fertility. Three farmers stated that termite mounds indicated fertile soil and two farmers said that the presence of many weeds was also an indicator of high soil fertility. All of the farmers also said that rice plants that grew vigorously and had dark green-colored leaves indicated high soil fertility. 


\subsection{Organic materials used by the farmers to improve paddy field soils}

The farmers used a total of nine different organic materials in their paddy fields, including 1) rice straw and stubble, 2) cattle and buffalo manure, 3) pig manure, 4) rice husks, 5) sunn hemp, 6) charcoal, 7) commercial compost, 8) homemade compost, and 9) tree leaf litter. Table 1 presents a summary of information about each of these residues, including how and when it is applied, the quantity used, its source, and any constraints on using it.

1) Rice straw and stubble: At the start of the rice planting season, all the farmers plowed under the rice straw and stubble remaining in the field from the previous harvest. They said that incorporating these residues makes the soil softer and less compact, whereas if they were to burn the straw and stubble the soil would become hard and difficult to plow. In the past herds of cattle and buffalo were allowed to freely graze in the fallow paddy fields during the dry season. They converted some of the stubble and straw into manure which remained in the fields where it was deposited. In recent years, however, some farmers have begun multiple cropping by planting sunn hemp or sugarcane in the paddy fields after the rice harvest, so livestock are no longer allowed to graze there. In addition, some farmers now prohibit grazing in their fallow fields because the animals sometimes breakdown the paddy bunds.

2) Cattle and buffalo manure: These residues are used as soil amendments by most of the farmers because they believe that they make the soil softer, less compact, and easier to plow. The farmers had observed that in the fields to which manure had been applied the rice plants were strong with deep green color and vigorous tillering. More manure is applied to plots with sandy soil than to those with fine-textured soil. Some farmers collected manure from the stables in their house compounds, and some purchased it from other farmers both in Non Ku village and from nearby villages for 30 baht (approximately USD 1.00) per 10-15 kg bag of dry manure. Manure is applied to the paddy fields in the dry season at an average rate of about $1,500 \mathrm{~kg} / \mathrm{ha}$. Farmers with an abundant supply of manure applied it every year but those with more limited quantities at their disposal applied it only every other year and sometimes only to the parts of their fields that had yielded poorly in the previous crop.

At present, the supply of cattle and buffalo manure is very limited because the number of large livestock is small. In the past, almost every household kept at least one buffalo as a draft animal but, since the widespread adoption of diesel-powered two-wheeled hand tillers in the 1990s eliminated the need for draft animals, the number of large livestock has greatly declined. At present, only 21 households raise large livestock to sell and there are only 48 head of cattle and 43 buffalo in the village. There are $472 \mathrm{ha}$ of paddy fields so the average stocking rate is only $0.19 \mathrm{head} / \mathrm{ha}$. Non Ku village is actually slightly better endowed than other villages in the area. In 2016 Mueang district of Khon Kaen province where Non Ku village is located had 44,486 ha of paddy fields but only 5,388 cattle and 1,004 buffalo (Khon Kaen Provincial Statistical Office, 2017; or an average of only $0.14 \mathrm{head} / \mathrm{ha}$.

3) Pig manure: Only one farmer, who raised one to three pigs each year, applied this type of residue at the time of this study. Another farmer had purchased pig manure in the past but no longer uses this amendment. The farmer who still used pig manure said that it makes the soil softer and easier to plow and makes the rice plants grow well but its beneficial effects are shorter-lived than those of cattle and buffalo manure. He applied 4-5 cartloads ( 1 cartload $=40 \mathrm{~kg}$ ) of dry manure per rai $\left(1,600 \mathrm{~m}^{2}\right)$ (which is equivalent to approximately $1.25 \mathrm{t} / \mathrm{ha}$ ) to a different part of his field during the dry season. If more pig manure was available, he would like to apply it to the whole field every year.

4) Rice husks: In the past, rice husks were used by some farmers to improve the texture of the soil in the nursery plots where rice seedlings were grown before being transplanted into the paddy fields. The farmers obtained rice husks from the village rice mill for free but more recently they have had to pay the mill 20 baht (USD 0.70) per $25 \mathrm{~kg}$ basket. They applied rice husks into the nursery plots in the dry season at a rate of about $100 \mathrm{~kg} / 300 \mathrm{~m}^{2}$ (equivalent to $3.3 \mathrm{t} / \mathrm{ha}$ ). They said that it was easy to pull out the seedlings from nurseries that had been treated with rice husks. However, after several years of applying this residue, these plots became infested with weeds because the rice husks were usually contaminated with weed seeds. Consequently, some farmers switched to 
treating their nurseries with gypsum, a commercial soil amendment that also made the soil less compact but did not spread weed seeds. In recent years many farmers have adopted broadcast seeding of their paddy fields, so they no longer need to use rice husks to improve the soil in the nurseries.

The farmers in Non Ku village are aware that farmers in other villages use rice husks to improve saline soil but do not engage in this practice themselves because there is no salt affecting the soil in their village.

5) Sunn hemp (Crotalaria juncea): Five farmers planted sunn hemp in their paddy fields after harvesting the rice. They obtained free seeds from the Land Development Department (LDD), which has been promoting sunn hemp as a green manure and cash crop for the past several years. After plowing the land, they broadcast the sunn hemp seeds onto the surface of the soil, and then harrowed the field. When the sunn hemp flowers, some farmers plow it into the soil as green manure, but most of them wait until they can harvest the seeds before plowing the plants into the soil. The farmers said that rice plants grown after sunn hemp remained a healthy green color for the whole season and displayed vigorous tillering. They also said that sunn hemp improved soil structure by making it less compact. Some farmers planted sunn hemp in all of their fields but those who kept cattle only sowed it on a small part of their land. LDD purchased sunn hemp seed from the farmers for $20 \mathrm{baht} / \mathrm{kg}$ but most farmers said they preferred to sell it to middlemen for $18 \mathrm{baht} / \mathrm{kg}$ because they received payment immediately.

6) Tree leaf litter: In the past, most farmers used tree leaf litter as a soil amendment but now fewer than half of them continue to do so due to their scarcity. There are two sources of tree leaf litter: A few farmers still follow the traditional Northeastern Thai practice of keeping many trees in their paddy fields (Pendleton, 1943; Vityakon, 1993). During the dry season, when many native trees shed their leaves, the leaf litter falls into the fields where it gradually decomposes. The most common species found in the paddy fields in Non Ku village are toothbrush trees (Streblus asper), which are called koi in the local language, eucalyptus ( $y u-k h a$ in the local language) and mango. There are both positive and negative consequences of having trees in the paddy fields. The decomposing leaves release nutrients and improve soil structure but the rice plants growing in the shade under the canopies yield poorly. The farmers said that eucalyptus leaves decomposed slowly, discolored the water in the paddy fields and reduced the yields of rice.

A second source of tree leaf litter is from trees growing inside house compounds which some farmers, who no longer have trees in their paddy fields, collected and transported to their fields. The main species included star gooseberry (local names are Ma-Yom or Buk-Yom, Phyllanthus acidus), custard apple (local name is Buk-Kiap, Annona squamosa), jujube (local name is Buk-Tan, Ziziphus) and bamboo (local name is Pai, Bambuseae sp.). Because there are only a few trees around each house, the quantity of leaves they shed is small, only enough to fill 5-10 rice sacks measuring $57.5 \times 92.5 \mathrm{~cm}$. In the dry season, these sacks are transported to the fields where the farmers spread the leaf litter on the surface of the soil in areas that had yielded poorly in the previous year. They said that the rice plants growing in treated fields had a healthy green color and gave high yields. In the past, some farmers had applied leaf litter collected from beneath the large rain trees (local name is Cham-Cha, Samaneasaman) that grew along the stream running near their paddy fields, but they no longer do this because the trees were cut down.

7) Commercial compost: Three farmers purchased commercial compost from salesmen who brought it to the village to sell. They paid $250-400 \mathrm{baht} / 50 \mathrm{~kg}$ bag. Farmers who transplanted rice applied this amendment about 7 to 15 days after transplanting the seedlings into the fields. The farmers who employed broadcast seeding first plowed their fields and then broadcast the commercial compost by hand before broadcasting the rice seeds, after which they harrowed the fields. They applied from 6 to 20 bags/ha $(300-1,000 \mathrm{~kg} / \mathrm{ha})$ in combination with cattle manure or chemical fertilizer. They said that the rice plants grew strongly and were free of disease.

8) Homemade compost: Some farmers received training from the LDD about how to produce their own compost. They make two types of compost, a liquid type made from kitchen waste, and a solid type made from a mixture of tree leaf litter, livestock manure, lime, and a manufactured starter provided by LDD. A typical household can produce about 20 liters of liquid compost and 2-3 $\mathrm{m}^{3}$ of 
solid compost each year. The liquid type is poured into water flowing into the paddy fields after the rice is already growing there. The solid compost is spread on the surface of the soil in a small part of the paddy field in the dry season in the same manner as manure. They said that the rice grew well with a dark green color in the fields that had been treated with homemade compost.

9) Charcoal: After some farmers observed that rice grew very well in the part of the paddy field where they had previously made charcoal in temporary kilns and where fragments of charcoal littered the surface of the soil, they began to collect small pieces of charcoal from other kilns to spread in the paddy fields. The available quantities are very small (about half of a rice sack per farmer) and they can treat only a very limited area with this residue. It is curious that the farmers never add wood ash from kitchen cooking fires to their paddy fields, although ash contains many mineral nutrients. They said that the ash was salty and damaged the rice plants.

\subsection{Recent changes in the use of organic soil amendments by the farmers}

The types of organic residues used by farmers to improve their paddy field soils have changed over the past 10 years. Some residues that were previously commonly used have become less popular while some new types of residues have recently appeared (Figure 2). Only use of rice straw and stubble have remained unchanged; all of the farmers continue to plow the rice straw and stubble remaining from the previous harvest into their fields at the beginning of the rainy season

In the past, all of the farmers used cattle and buffalo manure, but in recent years seven farmers have stopped applying these residues because they no longer keep livestock. Of the five farmers who currently apply livestock manure, three of them obtain manure from their own livestock and two buy it from outside the village. Only one farmer currently applies pig manure and three farmers used to applied it but have stopped because the number of pigs in the village has greatly declined due to the high price of the rice bran used to feed them. At present, five farmers apply tree leaf litter to their fields while three farmers who formerly applied this residue have stopped because they can no longer collect enough leaves.

In recent years, planting of sunn hemp for green manure has been promoted by the government Land Development Department. Five farmers currently plant sunn hemp in their fields. They harvest the seeds to sell and save some seed for their own use. The plant residues are plowed into the fields at the start of the rainy season. One farmer has stopped planting sunn hemp because he failed to save the seed and another farmer discontinued planting this green manure crop because he now uses his fallowed paddy field to pasture his cattle.

Three farmers currently apply commercial compost and four farmers used to apply it but have stopped because it is quite expensive (about 300-400 baht/50 kg bag). These farmers also complained that the commercial compost worked much more slowly than chemical fertilizer (costing $500 \mathrm{baht} / 50 \mathrm{~kg}$ bag). Three farmers currently apply homemade compost to their paddy fields. Although making compost has been actively promoted by LDD, adoption has been limited because collecting the raw materials and making the composts requires a lot of time and energy.

Only one farmer currently applies charcoal in his field while six farmers have stopped using it because it is difficult to find wood to make charcoal. Four farmers used to apply rice husks to the nurseries for rice seedlings as well as some parts of their paddy fields where the soil was too compact, but they have now stopped because the price charged by the mill for this residue has become too high. Instead, they now purchase gypsum from local shops to soften the soil and make it less compact.

\subsection{Do the farmers have a concept of organic matter?}

The fact that the farmers in Non Ku village employ a wide range of organic residues to improve the soil quality in their paddy fields does not necessarily mean that they have a general concept of organic matter or understand what it is or how it affects soil quality. In order to better understand how they think about organic matter, we presented each farmer with samples of eight different commonly used soil amendments (chemical fertilizer, lime, sunn hemp plants, tree leaf litter, rice straw, rice husks, pig manure, and cattle manure) and asked them to sort the samples into similar groups. Five farmers divided the samples into two groups: A chemical group and a non-chemical group. two of these farmers called the non-chemical group "natural fertilizer," one farmer called it 
"local fertilizer," one farmer called it "organic fertilizer," and one farmer called it simply "fertilizer." It appears that the farmers think of natural fertilizer and organic fertilizer as materials that they can get from nature, such as animal manure, tree leaf litter, rice straw, rice husks. By "Local fertilizer" the farmers meant amendments that can be obtained within their community, for example tree leaf litter, rice husks, rice straw, and cattle and buffalo manure.

Four farmers divided the soil amendment samples into three groups. Three of them separated the samples into three groups that consisted of chemical fertilizer, lime, and non-chemical amendments which they variously called the non-chemical group "decomposable material," "natural fertilizer," and "organic fertilizer." One farmer classified the samples into a "chemical group" (chemical fertilizer and lime), a "livestock manure group" (cattle manure and pig manure), and a "plant fertilizer group" (sunn hemp plants, tree leaf litter, rice husks, and rice straw). Three farmers placed all the soil amendment samples into a single group which they called simply the "fertilizer group."

Although the majority of the farmers distinguished organic from inorganic amendments, they did not appear to have a clearly delineated concept of organic matter, instead they categorized amendments according to their sources (e.g. natural or local) or specific characteristics (e.g. animal manure or plant fertilizer). The lack of a general concept of organic matter is hardly surprising since there is no commonly used word for "organic" in the local language. The few farmers who used the term "organic" employed the Central Thai word insee, which has been popularized in recent years by government agencies and NGOs seeking to promote more sustainable farming practices.

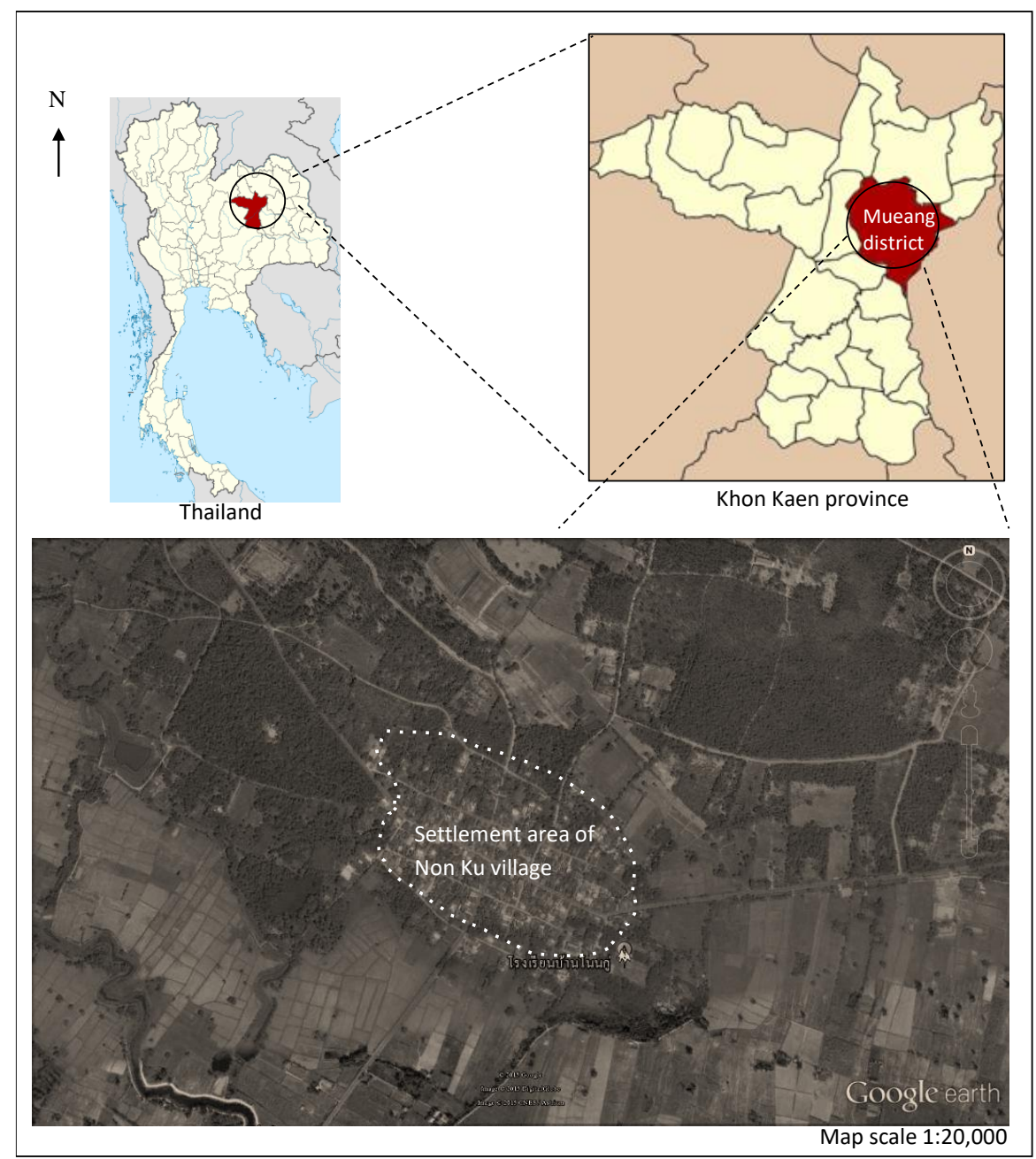

Figure 1. Map showing location of Non Ku village in Thailand

Note on sources of maps: Thailand: https://bit.ly/2FhYJyP; Khon Kaen province: https://bit.ly/2Oky74J; Non Ku village: drawn by authors on Google Maps image 


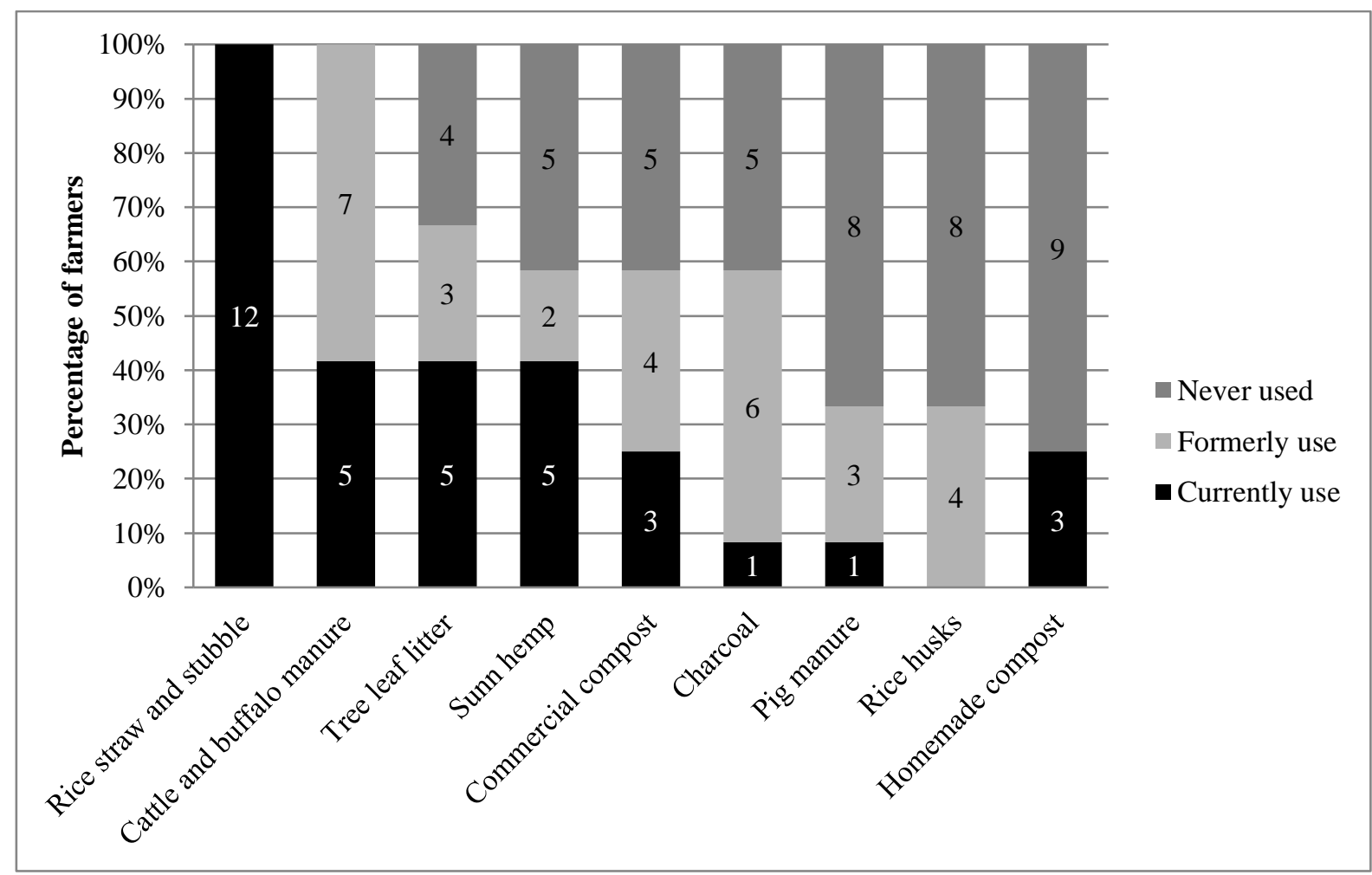

Figure 2. Changes in the use of different organic soil amendments by farmers in Non Ku village 
Table 1 Organic materials used by farmers to improve soil quality and fertility in their paddy fields in Non Ku village

\begin{tabular}{|c|c|c|c|c|c|c|c|}
\hline Types of residue & $\begin{array}{l}\text { No. of } \\
\text { farmers } \\
\text { using }\end{array}$ & $\begin{array}{l}\text { Effect on soil and } \\
\text { plant growth }\end{array}$ & $\begin{array}{l}\text { Application } \\
\text { method }\end{array}$ & Where applied & When applied & Constraints on use & Sources \\
\hline $\begin{array}{l}\text { Cattle and buffalo } \\
\text { manure }\end{array}$ & $\begin{array}{l}10 \\
(83.3)\end{array}$ & $\begin{array}{l}\text { - Soil less compact } \\
\text { and easy to plow } \\
\text { - Rice plants are } \\
\text { green color and } \\
\text { have many tillers }\end{array}$ & $\begin{array}{l}\text { Spread by } \\
\text { dragging the open } \\
\text { bags across the } \\
\text { field }\end{array}$ & Paddy field & Dry season & Limited supply & $\begin{array}{l}\text { Own stable or } \\
\text { purchased from } \\
\text { other farmers }\end{array}$ \\
\hline Pig manure & $\begin{array}{l}1 \\
(8.3)\end{array}$ & $\begin{array}{l}\text { - Soil less compact } \\
\text { and easy to plow } \\
\text { - Rice plants are } \\
\text { green color and } \\
\text { have many tillers }\end{array}$ & $\begin{array}{l}\text { Spread by } \\
\text { dragging the open } \\
\text { bags across the } \\
\text { field }\end{array}$ & Paddy field & Dry season & Limited supply & Own pigsty \\
\hline $\begin{array}{l}\text { Green manure (Sunn } \\
\text { hemp) }\end{array}$ & $\begin{array}{l}5 \\
(41.7)\end{array}$ & $\begin{array}{l}\text { Rice plants are } \\
\text { green color butt } \\
\text { may grow too tall } \\
\text { and have many } \\
\text { tillers }\end{array}$ & $\begin{array}{l}\text { After broadcast } \\
\text { seeding, the field } \\
\text { is plowed. When } \\
\text { the plants are } \\
\text { mature, they are } \\
\text { plowed into the } \\
\text { soil. }\end{array}$ & Paddy field & $\begin{array}{l}\text { After the rice } \\
\text { harvest }\end{array}$ & $\begin{array}{l}\text { High cost of } \\
\text { multiple tillage } \\
\text { operations. Seeds } \\
\text { are difficult to } \\
\text { obtain }\end{array}$ & $\begin{array}{l}\text { Seed distributed by } \\
\text { the Land } \\
\text { Development } \\
\text { Department or } \\
\text { saved from } \\
\text { previous crop }\end{array}$ \\
\hline Rice husks & $\begin{array}{l}1 \\
(8.3)\end{array}$ & $\begin{array}{l}\text { Seedlings are easy } \\
\text { to pull out }\end{array}$ & $\begin{array}{l}\text { The farmers were } \\
\text { collected and put } \\
\text { in bag and then } \\
\text { drop or spread } \\
\text { residues into } \\
\text { paddy field }\end{array}$ & Nursery & Dry season & $\begin{array}{l}\text { Limited supply and } \\
\text { high cost }\end{array}$ & $\begin{array}{l}\text { Purchased from } \\
\text { rice mills }\end{array}$ \\
\hline $\begin{array}{l}\text { Rice straw and } \\
\text { stubble }\end{array}$ & $12(100.0)$ & $\begin{array}{l}\text { Soil is less } \\
\text { compact }\end{array}$ & $\begin{array}{l}\text { The farmers plow } \\
\text { under at the } \\
\text { beginning of the } \\
\text { rainy season }\end{array}$ & $\begin{array}{l}\text { Nursery and } \\
\text { paddy field }\end{array}$ & None & None & Own fields \\
\hline Tree leaf litter & 1 & Rice plants are & After collecting & & Dry season & Very limited supply & House compound \\
\hline
\end{tabular}




\begin{tabular}{|c|c|c|c|c|c|c|c|}
\hline & (8.3) & $\begin{array}{l}\text { green color and } \\
\text { have many tillers }\end{array}$ & $\begin{array}{l}\text { fallen leaves in } \\
\text { bags, the farmers } \\
\text { spread them on } \\
\text { the top of the soil } \\
\text { by hand. }\end{array}$ & & & & \\
\hline Charcoal & $\begin{array}{l}1 \\
(8.3)\end{array}$ & $\begin{array}{l}\text { Rice plants are } \\
\text { green color and } \\
\text { have many tillers }\end{array}$ & $\begin{array}{l}\text { Spread around the } \\
\text { field by hand }\end{array}$ & Paddy field & Dry season & $\begin{array}{l}\text { Difficult to make } \\
\text { and difficult to find } \\
\text { the material }\end{array}$ & $\begin{array}{l}\text { Make it } \\
\text { themselves in } \\
\text { simple kilns }\end{array}$ \\
\hline $\begin{array}{l}\text { Commercial } \\
\text { compost }\end{array}$ & $\begin{array}{l}2 \\
(16.7)\end{array}$ & $\begin{array}{l}\text { Rice plants are } \\
\text { green color and } \\
\text { have many tillers }\end{array}$ & $\begin{array}{l}\text { Either broadcast a } \\
\text { few weeks after } \\
\text { transplanting or } \\
\text { broadcast at the } \\
\text { same time as the } \\
\text { rice seeds }\end{array}$ & Paddy field & $\begin{array}{l}\text { Planting } \\
\text { season }\end{array}$ & High cost & $\begin{array}{l}\text { Purchase from } \\
\text { salesmen }\end{array}$ \\
\hline Homemade compost & $\begin{array}{l}1 \\
(8.3)\end{array}$ & $\begin{array}{l}\text { Rice plants are } \\
\text { green color and } \\
\text { have many tillers }\end{array}$ & $\begin{array}{l}\text { Spread in the field } \\
\text { by hand }\end{array}$ & Paddy field & Dry season & $\begin{array}{l}\text { Requires labor and } \\
\text { time to make }\end{array}$ & Make at home \\
\hline
\end{tabular}

Note: The numbers inside the parentheses are the percentages of respondents using different organic materials 


\section{Discussion}

The farmers in Non Ku village employed a number of different indicators of soil quality, including physical indicators (soil color and texture) and biological indicators (earthworms, rice plant vigor and leaf color) to assess soil quality and fertility. These indicators are similar to those employed by other traditional farmers elsewhere in the world. According to Kuria et al. (2018) soil color, indicator plants, crop vigor, and soil texture are the most commonly used indicators of soil quality. Not surprisingly, however, they use far fewer indicators than modern soil scientists, who rely on diverse chemical, physical, and biological indicators. Commonly used chemical indicators include $\mathrm{pH}$, salinity, soil organic carbon, and total nitrogen (Nael et al., 2004). Physical indicators include aggregate stability, soil structure, available water capacity, bulk density, infiltration, porosity, slaking, texture and compaction (Schloter et al., 2003). Biological indicators include the presence of various plant and animal species (Barrios, 2007).

Like other traditional farmers in other parts of the world, the farmers in Non Ku village apply many different kinds of organic residues to improve the soil in their fields. These include rice straw and stubble, cattle and buffalo manure, pig manure, rice husks, sunn hemp, tree leaf litter, commercial compost, homemade compost, and charcoal. Unlike traditional farmers in China, Japan, Korea (Kawa et al., 2019) and Ghana (Cofie et al., 2005), the farmers in Northeast Thailand have never used human night soil as an organic soil amendment in their paddy fields. This may reflect the fact that in the past Northeastern farmers had such abundant supplies of animal manure that they had no need to resort to night soil. Until the vast expansion of the area planted to upland cash crops in the 1970s, livestock were a main source of cash income for rural households and herd sizes were much larger than they are today (Pendleton, 1943). According to a historical study of the agroecology of Hin Lad village in Khon Kaen province (Subhadira et al., 1988) each household kept on average 30 head of cattle and buffalo, so had ample supplies of manure for their paddy fields. Moreover, although the amount of organic matter in northeastern agricultural soils is now very low, this was not such a serious problem in the past when most rice was grown in lower paddy fields which have higher clay and SOM levels than the more recently constructed upper paddy fields (Rigg, 1985; Watanabe, 2017; Watanabe et al., 2017). Indeed, a national agricultural survey in the 1930s found that rice yields in Northeast Thailand were higher than in Central Plain (Zimmerman, 1931). A further factor contributing to the higher SOM levels in the past was the prevalence of trees in the paddy fields which provided abundant leaf litter to replenish organic matter in the soil. In recent years, however, tree densities have sharply declined with consequent diminishment of the quantity of leaf litter falling into the paddy fields (Watanabe et al., 2014; Watanabe et al., 2017)

The farmers make no use of wood ash from cooking fires to amend their paddy soils. They believe it damages the rice plants although some other subsistence farmers including those in the Red River Delta of Vietnam (A. T. Rambo, personal observation) and Ethiopia (Tegene, 1998) place a high value on this organic residue. It is noteworthy that several farmers have independently discovered that charcoal is a useful organic amendment that improves rice yields since it is only quite recently that biochar became a major focus of research among soil scientists (Sohi et al., 2010).

The suite of organic residues used by the farmers in Non Ku is not static, but has changed over time according to changes in the availability and cost of different materials, as well as the partial displacement of organic sources of nutrients by cheap and fast-acting chemical fertilizers. Many locally available residues that were used by most farmers in the past (e.g., livestock manure, rice husks, tree leaf litter) are now much less commonly used because of scarcity and/or increased prices, while several new organic materials have recently been adopted (e.g., green manure and compost). Although some farmers had stopped using these new amendments at the time of this study, this reflects the difficulties they had recently encountered in obtaining seed for sunn hemp, the main green manure crop grown in the village, and shortages of suitable feedstocks for making compost and charcoal, rather than any loss of interest on the part of the farmers in using these amendments. The dynamic character of farmer selection of organic materials suggests that they will be receptive to adopting new types of organic materials if these are compatible with their farming system. Earlier efforts by LDD to promote growing of green manure crops (e.g., stylosanthes and 
sesbania) in Northeast Thailand largely failed because farmers had to expend extra cash and labor to grow them but received no direct cash benefits in return (Homma et al., 2009). In contrast, adoption of sunn hemp has been relatively rapid since sale of the seeds provides some cash income to the farmers growing this crop.

In lacking a general concept of soil organic matter in their indigenous soil knowledge system, the farmers in Non Ku village resemble traditional farmers elsewhere in the world. Although it has often been stated that the organic matter content of soil is used as an indicator of soil fertility by farmers from many different ethnic groups in Asia, Africa, Europe and the Americas, there is scant empirical support for this view. For example, Barrera-Bassols and Zink (2003: 178, Table 3) report that almost half $(47 \%)$ of the 62 ethnic groups whose soil classification systems they reviewed employed organic matter content to classify soils, they provided no information about how they identified indigenous terms for organic matter in soil names. We suspect that the researchers had inferred that organic matter is the classificatory criterion when the native name does not actually include this term, but instead refers to an associated characteristic of SOM. Having a black or dark brown color is perhaps the most commonly cited attribute (Hossain, 2001; Quansah et al., 2001). Being "fatty" and having the odor of fresh organic matter are also sometimes mentioned by farmers (Quansah et al., 2001:201). A study of soil quality indicators used by wet rice farmers in southern Brazil (Lima et al., 2011: 34, Table 4) reported that 57 percent of their 32 informants used organic matter content as an indicator of soil fertility but the actual responses of the farmers appear to have employed the term "fat," and did not use the term "organic matter." Thus, one farmer is quoted as saying that "A good soil is a black soil, which has more fat (organic matter) in it" and another said that "If the soil has fat it means a stronger soil, with more nutrients, so it is more fertile." Another example is provided by Hossain (2001: 198), who, in his paper on farmer knowledge of SOM in Bangladesh, states that,

".... the farmers have realized that soil organic matter is declining. 'Jomishoktohoigeche' (the soil has become hard), is one of the most common phrases expressed by the farmers."

He further states that,

"Farmers say that organic matter increases yield, reduces the production cost, improves crop growth and their economy, increases water-holding capacity and improves soil structure. They recognize a soil with a higher organic matter content by a darker, brownish to black color. Farmers realize that they can increase the organic matter content of the soils in the fields by adding cow dung and other organic manure or by leaving crop residues in the field" (Ibid: 199).

But Hossain (2001) provides no evidence that farmers actually have a general concept of SOM, only that they recognize that addition of certain amendments can improve soil structure and increase crop yields.

We have not encountered any convincing evidence in the ethnopedological literature that traditional farmers had a clearly defined concept of soil organic matter as a general category or recognized the role that SOM plays in maintaining overall soil quality. Instead, they had knowledge gained from trial and error experience that soils with a black color or greasy feel gave higher yields and that application to their fields of certain types of residues that modern soil scientists lump together under the rubric of "organic matter" resulted in higher yields.

Support for our view that traditional farmers lack a generalized concept of SOM is offered by the study by Ryder (2003) of peasant farmers in the mountains of the Dominican Republic. Those farmers who identified black soil as a distinct local soil type said it was the most fertile soil in their community but fewer than half of them recognized that its black coloration was caused by its high organic matter content (Ryder, 2003). Similarly, Grossman (2003) reported that Maya organic coffee farmers in Chiapas, Mexico, understood that decomposition of leaf litter from $\mathrm{N}$-fixing shade trees improved soil fertility but they did not appear to recognize that SOM improved soil texture, only that the soil became black-colored and the coffee grew better. He explained this apparent gap in farmer knowledge as follows: 
"The farmer's [sic] comprehension of the role of leaf litter in soil formation is most likely due to their ability to see the decomposition process in action over time, as opposed to other processes that cannot be observed with the naked eye."

It is hardly surprising that the farmers in Non Ku village, like many traditional farmers elsewhere in the world, lack a clearly articulated concept of SOM. After all, it was only in the late 1800s that Western soil scientists first formulated a clear concept of soil organic matter (Vityakon, 2011).

\section{Conclusions}

The findings of this study have both theoretical and practical significance. From the theoretical perspective, the study suggests that the farmers lack a general concept of soil organic matter. Instead, they recognize that specific organic materials improve soil quality. Additional investigations should be made of different ethnic groups in other parts of the world to establish if this is a common aspect of indigenous soil knowledge systems. From a practical perspective, this study has implications for the strategies of agricultural extension agents in their efforts to promote organic farming. Additional research aimed at overcoming supply constraints on farmer use of organic amendments is also suggested.

Although the farmers in Non Ku village lack a general concept of soil organic matter, they recognize that many materials that scientists classify as organic materials are useful for improving soil quality and fertility in their paddy fields. That the farmers lack an overarching concept of organic matter is hardly surprising given that their soil knowledge is largely derived from trial-and-error experience in managing their fields. As is illustrated by the chance discovery of a few farmers adding charcoal to the soil to help produce better yields, the farmers have simply observed the impacts that different amendments have had on rice yields over the years and have continued using those that give desired results. Agricultural extension agents should take the highly specific nature of farmer knowledge into account so that, rather than promoting "organic agriculture," a scientific concept that cannot even be translated into the local language, they should instead promote use of specific organic amendments to improve soil quality.

A majority of the farmers already want to use organic amendments to improve soil quality in their fields, so it seems unnecessary for agricultural extension agents to expend time and energy promoting this practice. Increased farmer adoption of organic amendments is primarily constrained by the scarcity and high cost of many traditionally used residues. Consequently, they are forced to rely on chemical fertilizer to a large extent to maintain crop yields. Finding ways to increase local supplies of organic materials is a critical problem that must be solved if efforts by the Thai government and NGOs to encourage more farmers in Northeast Thailand to adopt organic agriculture are to be successful. A first step towards achieving this goal would be to make detailed inventories of the quantities of different organic amendments that are potentially available to farmers in specific rural communities. When supplies are found to be inadequate, research needs to be done on both increasing the effectiveness with which existing materials are used and on increasing the supply of materials. For example, mixing low quality residues (e.g., rice straw) together with high quality residues (e.g., peanut stover) may result in higher retention of carbon in the topsoil (Patma Vityakon, pers. comm.) which could improve the efficiency with which limited residue supplies are used. The supply of organic materials could be increased by finding ways to fit more trees into the farm landscape (e.g., planting trees on paddy bunds) or finding catch crops that provide cash income to farmers while simultaneously supplying them with green manure (e.g., planting peanuts after the rice harvest).

Finding ways to increase farmer use of organic residues is, of course, a problem that extends far beyond the boundaries of one small Northeastern Thai village; it is global in scope, but especially critical in the tropics where vast areas of farmland are already severely degraded and there are many competing demands for limited available supplies of organic materials.

Author contributions: Sujitra Yodda: Conceptualization, Methodology, Validation, Formal Analysis, Investigation, Data Curation, Writing Original Draft, Writing-Review and Editing, Visualization, Funding Acquisition; Suwit Laohasiriwong: Formal Analysis, Writing-Review and Editing, Visualization, Supervision, 
Funding Acquisition; A. Terry Rambo: Conceptualization, Methodology, Validation, Formal Analysis, Writing Original Draft, Writing-Review and Editing, Visualization, Supervision, Project Administration, Funding Acquisition

Competing interests: The authors declare that they have no known competing financial interests or personal relationships that could have appeared to influence the work reported in this paper.

Acknowledgments: This research was supported by a scholarship awarded to the first author under the PostDoctoral Training Program from Khon Kaen University, Thailand. Additional support was provided by the Soil Organic Matter Management Research Group of Khon Kaen University. Patma Vityakon made useful suggestions about how to improve an earlier draft of this paper. We would also like to express our gratitude to the farmers in Non Ku village for their willingness to participate in this research.

\section{References}

Barrera-Bassols, N., \& Zinck, J. A. (2003). Ethnopedology: a worldwide view on the soil knowledge of local people. Geoderma,111(3-4), 171-195. https://doi.org/10.1016/S00167061(02)00263-X

Barrios, E. (2007). Soil biota, ecosystem services and land productivity. Ecological economics, 64(2), 269-285. https://doi.org/10.1016/j.ecolecon.2007.03.004

Cofie, O. O., Kranjac-Berisavljevic, G., \& Drechsel, P. (2005). The use of human waste for peri-urban agriculture in Northern Ghana. Renewable Agriculture and Food Systems, 20(2), 73-80. https://doi.org/10.1079/RAF200491

Ellis, E. C., \& Wang, S. M. (1997). Sustainable traditional agriculture in the Tai Lake Region of China. Agriculture, Ecosystems \& Environment, 61(2-3), 177-193. https://doi.org/10.1016/S0167-8809(96)01099-7

Grossman, J. M. (2003). Exploring farmer knowledge of soil processes in organic coffee systems of Chiapas, Mexico. Geoderma, 111(3-4), 267-287. https://doi.org/10.1016/S00167061(02)00268-9

Hijbeek, R., Pronk, A. A., Van Ittersum, M. K., ten Berge, H. F. M., Bijttebier, J., \& Verhagen, A. (2018). What drives farmers to increase soil organic matter? Insights from the Netherlands. Soil Use and Management, 34(1), 85-100. https://doi.org/10.1111/sum.12401

Homma, K., Mochizuki, A., Horie, T., Shiraiwa, T., \& Supapoj, N. (2009). Nutrient deficiency in the rice-stylo (Stylosanthes guianensis) relay-intercropping system in rainfed lowland rice ecosystem in Northeast Thailand.Plant Production Science, 12(3), 390-393. https://doi.org/10.1626/pps.12.390

Hossain, M. Z. (2001). Farmer's view on soil organic matter depletion and its management in Bangladesh. Nutrient Cycling in 197-204. https://doi.org/10.1023/A:1013376922354

Kawa, N. C., Ding, Y., Kingsbury, J., Goldberg, K., Lipschitz, F., Scherer, M., \& Bonkiye, F. (2019). Night Soil. Ethnobiology Letters, 10(1), 40-49. https://doi.org/10.14237/ebl.10.1.2019.1351

Khon Kaen Provincial Statistical Office. 2017. Khon Kaen Provincial Statistical Report. 2017. Retrieved from https://issuu.com/khonkaen.nso.go.th/docs/1aa3e08374d6ee

Kuria, A. W., Barrios, E., Pagella, T., Muthuri, C. W., Mukuralinda, A., \& Sinclair, F. L. (2019). Farmers' knowledge of soil quality indicators along a land degradation gradient in Rwanda. Geoderma regional, 16, e00199. https://doi.org/10.1016/j.geodrs.2018.e00199

Lima, A. C. R., Hoogmoed, W. B., Brussaard, L., \& Dos Anjos, F. S. (2011). Farmers' assessment of soil quality in rice production systems. NJAS-Wageningen Journal of Life Sciences, 58(1-2), 31-38. https://doi.org/10.1016/j.njas.2010.08.002

Marten, G.G., and P. Vityakon . 1986. Soil Management in Traditional Agriculture. In Marten, G.G. (Ed.), Traditional Agriculture in Southeast Asia: A Human Ecology Perspective (pp. 199-225). Westview Press.

McNeill, J. R., \& Winiwarter, V. (2004). Breaking the sod: Humankind, history, and soil. Science, 304(5677), 1627-1629. https://doi.org/10.1126/science.1099893

Miyagawa, S., Koyama, Y., Kokubo, M., Matsushita, Y., Adachi, Y., Sivilay, S., ... \& Oba, S. (2011). 
Indigenous utilization of termite mounds and their sustainability in a rice growing village of the central plain of Laos. Journal of Ethnobiology and Ethnomedicine, 7(1), 1-6. https://doi.org/10.1186/1746-4269-7-24

Nael, M., Khademi, H., \& Hajabbasi, M. A. (2004). Response of soil quality indicators and their spatial variability to land degradation in central Iran. Applied Soil Ecology, 27(3), 221-232. https://doi.org/10.1016/j.apsoil.2004.05.005

Quansah, C., Drechsel, P., Yirenkyi, B. B., \& Asante-Mensah, S. (2001). Farmers' perceptions and management of soil organic matter-a case study from West Africa. Nutrient Cycling in Agroecosystems, 61(1), 205-213. https://doi.org/10.1023/A:1013337421594

Pendleton, R. L. (1943). Land use in northeastern Thailand. Geographical review, 33(1), 15-41. https://doi.org/10.2307/210616

Pilbeam, C. J., Mathema, S. B., Gregory, P. J., \& Shakya, P. B. (2005). Soil fertility management in the mid-hills of Nepal: Practices and perceptions. Agriculture and Human Values, 22(2), 243-258. https://doi.org/10.1007/s10460-004-8284-y

Rigg, J. D. (1985). The role of the environment in limiting the adoption of new rice technology in Northeastern Thailand. Transactions of the institute of British Geographers, 10(4), 481-494. https://doi.org/10.2307/621893

Ryder, R. (2003). Local soil knowledge and site suitability evaluation in the Dominican Republic. Geoderma, 111(3-4), 289-305. https://doi.org/10.1016/S0016-7061(02)00269-0

Schloter, M., Dilly, O., \& Munch, J. C. (2003). Indicators for evaluating soil quality. Agriculture, Ecosystems \& Environment, 98(1-3), 255-262. https://doi.org/10.1016/S01678809(03)00085-9

Sohi, S. P., Krull, E., Lopez-Capel, E., \& Bol, R. (2010). A review of biochar and its use and function in soil. Advances in agronomy, 105, 47-82. https://doi.org/10.1016/S0065-2113(10)05002-9

Subhadira, S., Simaraks, S., Samart, M., and V. Limpinuntana. (1988). Changes in systems properties of Ban Hin Lad, a village agroecosystem in Northeast Thailand. In, K. Rerkasem and A. T. Rambo (Eds.), Agroecosystem Research for Rural Development (pp. 79-102). Chiang Mai (Thailand): Multiple Cropping Center, Chiang Mai University, and the Southeast Asian Universities Agroecosystem Network (SUAN).

Tegene, B. (1998). Indigenous soil knowledge and fertility management practices of the South Wällo Highlands. Journal of Ethiopian Studies, 31(1), 123-158. https://www.jstor.org/stable/41966079

Vaiglova, P., Bogaard, A., Collins, M., Cavanagh, W., Mee, C., Renard, J., ... \& Fraser, R. (2014). An integrated stable isotope study of plants and animals from Kouphovouno, southern Greece: a new look at Neolithic farming. Journal of Archaeological Science, 42, 201-215. https://doi.org/10.1016/j.jas.2013.10.023

Vityakon, P. (1993). The traditional trees-in-paddy-fields agroecosystem of Northeast Thailand: Its potential for agroforestry development. Regional Development Dialogue, 14(1), 125-148.

Vityakon, P. (2011). Soil organic matter and soil quality in Northeast Thailand. Department of Plant of Agriculture, Khon Kaen University, Khon Kaen, Thailand.

Watanabe, K. (2017). Improvement in rainfed rice production during an era of rapid national economic growth: a case study of a village in Northeast Thailand. Southeast Asian Studies, 6(2), 293-306. https://doi.org/10.20495/seas.6.2_293

Watanabe, M., Vityakon, P., \& Rambo, A. T. (2017). Factors Influencing Variations in the Density, Extent of Canopy Cover, and Origin of Trees in Paddy Fields in a Rainfed Rice-Farming Village in Northeast Thailand. Southeast Asian Studies, 6(2), 307-324. https://doi.org/10.20495/seas.6.2_307

Watanabe, M., Vityakon, P., \& Rambo, A. T. (2014). Can't see the forest for the rice: Factors influencing spatial variations in the density of trees in paddy fields in northeast Thailand. Environmental management, 53(2), 343-356. https://doi.org/10.1007/s00267-0130206-6

Yodda, S., \& Rambo, A. T. (2018). Lack of consensus about indigenous soil knowledge among wet rice farmers in a Thai-Lao village in $\mathrm{N}$ ortheast $\mathrm{T}$ hailand. Land Degradation \& 
Development, 29(11), 4121-4128. https://doi.org/10.1002/ldr.3166

Yodda, S. 2019. Indigenous soil knowledge of Thai-Lao farmers in Northeast Thailand (Doctoral dissertation). Khon Kaen University, Thailand.

Yodda, S., Laohasiriwong, S., \& Rambo, A. T. (2020). Naming, Classification, and management of paddy soils by Thai-Lao rice farmers in a village in Northeast Thailand. Geoderma, 369, 114332. https://doi.org/10.1016/j.geoderma.2020.114332

Zimmerman, C. C. 1941. Siam Rural Economic Survey, 1930-31. Bangkok Times Press. 